University for Business and Technology in Kosovo

UBT Knowledge Center

UBT International Conference

2015 UBT International Conference

Nov 7th, 9:00 AM - 5:00 PM

\title{
Climate Change and Drinking Water
}

Muhamet Ahmeti

University for Business and Technology, muhamet.ahmeti@ubt-uni.net

Ilira Abdullahu

University for Business and Technology, ilir.abdullahu@ubt-uni.net

Follow this and additional works at: https://knowledgecenter.ubt-uni.net/conference

Part of the Civil Engineering Commons, and the Structural Engineering Commons

\section{Recommended Citation}

Ahmeti, Muhamet and Abdullahu, Ilira, "Climate Change and Drinking Water" (2015). UBT International Conference. 80.

https://knowledgecenter.ubt-uni.net/conference/2015/all-events/80

This Event is brought to you for free and open access by the Publication and Journals at UBT Knowledge Center. It has been accepted for inclusion in UBT International Conference by an authorized administrator of UBT Knowledge Center. For more information, please contact knowledge.center@ubt-uni.net. 


\title{
Climate Change and Drinking Water
}

\author{
Muhamet Ahmeti ${ }^{1}$, Ilir Abdullahu ${ }^{2}$ \\ 1,2 UBT - Higher Education Institution \\ $\left\{\right.$ muhamet.ahmeti ${ }^{1}$, ilir.abdullahu $\left.{ }^{2}\right\} @$ ubt-uni.net
}

\begin{abstract}
The period June 2012 - M arch 2014 saw a prolonged deficit of precipitation below normal. This led to a major continental scale drought across southern Europe, and in eastern Kosova in particular. E.g. see figure 1 below for the month of December 2013, from Drought Monitoring Center for SEE. In fact December 2013 was the fifth driest month in the recorded history of Kosova.

February registered the driest month in the recorded hydro-meteorological history of Kosova, since 1927 with only $2.1 \mathrm{~mm}$ precipitation, which expressed in Standardized Precipitation Index (SPI). The chance of getting this value in February was 1 in 156. So, since June 2013, consecutively there were dry month, i.e. there was rainfall deficit (a meteorological drought) that consequently led to a hydrological drought. By March 2014 the water supply reservoirs of Batllava, Badovc were at $20 \%$ of normal levels, and nearly exhausted. There was approximately not more than 6-8 weeks of water supply remaining for upwards of 500,000 citizens.

Situation of drinking water supply was becoming much more difficult to citizens of Prishtina, Podujeva, Kastriot, Fushe Kosova and Gracanica. Thus, water supply restrictions hours were growing and there was a fear to citizens for the lack of water and at the same time were aware for a maximum of water saving. The Government Local and Central authorities, other Institutions, NGO's, were mobilized in order to find a solution, even for a temporary time, to deal with drought periods. There were few choices as the underground water level was affected by droughts and the only hope was the alternative supply from the Lake Ujmani (Gazivoda) where through the steel pipe fill Badovc Lake. Although, the pipe was not in a good condition because since year 1986 only once was included for operation to the system to fill Badovc Lake in 1996 as the water level fell at this Lake.
\end{abstract}

Keywords: Drought, Standardized Precipitation Index (SPI), Reservoirs levels, water losses

\section{Introduction}

The period June 2012 - March 2014 saw a prolonged deficit of precipitation below normal. This led to a major continental scale drought across southern Europe, and in eastern Kosova in particular. E.g. see figure 1 below for the month of December 2013, from Drought Monitoring Center for SEE. In fact December 2013 was the fifth driest month in the recorded history of Kosova. 


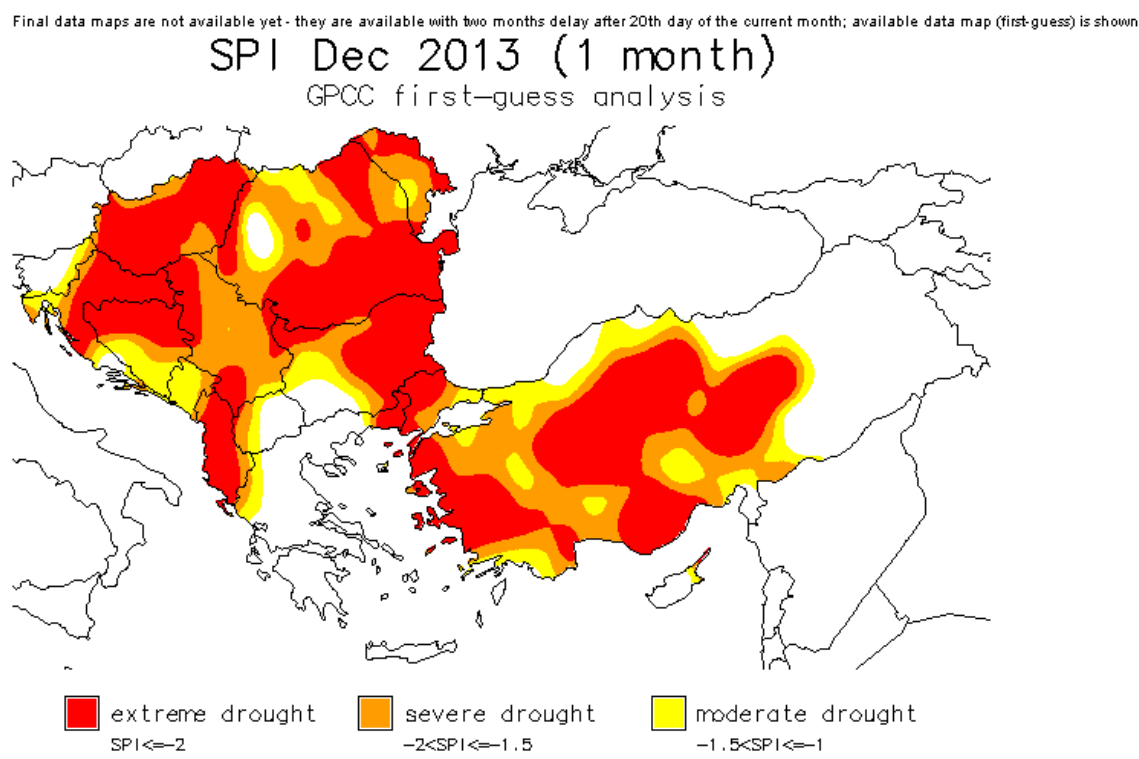

Figure 1 December 2013 continental drought

\subsection{Analyze the situation.}

February registered the driest month in the recorded hydro-meteorological history of Kosova, since 1927 with only $2.1 \mathrm{~mm}$ precipitation, which expressed in Standardized Precipitation Index (SPI) was -2.49 (fig. 2). The chance of getting this value in February was 1 in 156. So, since June 2013, consecutively there were dry month, i.e. there was rainfall deficit (a meteorological drought) that consequently led to a hydrological drought.

One of the most effective Early Warning Indicators is a simple measure of monthly precipitation expressed in terms of its deviation (from the average value for the last 1, 3, 6, 12 months). This is the Standardized Precipitation Index - SPI. The index ranges between +3.0 to -3.0 . The SPI is used throughout Europe as an early indicator of precipitation deficits or surpluses, which, if they continue, may lead to significant water scarcity (or flood) conditions respectively.

\begin{tabular}{|c|c|l|l|}
\hline \multicolumn{1}{l|l}{$\begin{array}{l}\text { SPI Value } \\
\sigma\end{array}$} & $\begin{array}{l}\text { Cumulative } \\
\text { Probability }\end{array}$ & Description & $\begin{array}{l}\text { Colour } \\
\text { Code }\end{array}$ \\
\hline+3.0 & 0.0014 & Extreme flood conditions & \\
\hline+2.5 & 0.0062 & & \\
\hline+2.0 & 0.0228 & Severe flood conditions & \\
\hline+1.5 & 0.0668 & & \\
\hline+1.0 & 0.1587 & Moderate flood conditions & \\
\hline+0.5 & 0.3085 & Precipitation slightly above normal & \\
\hline 0.0 & 0.5000 & Precipitation conditions fit long-term average & \\
\hline-0.5 & 0.6915 & Precipitation slightly below normal & \\
\hline-1.0 & 0.8413 & Moderate drought conditions & \\
\hline-1.5 & 0.9332 & & \\
\hline-2.0 & 0.9772 & Severe drought conditions & \\
\hline-2.5 & 0.9938 & & \\
\hline-3.0 & 0.9986 & Extreme drought conditions & \\
\hline
\end{tabular}

Fig.2 Standardized Precipitation Index (SPI

February registered the driest month in the recorded hydro-meteorological history of Kosova, since 1927 with only $2.1 \mathrm{~mm}$ precipitation, which expressed in Standardized Precipitation Index (SPI) was 
-2.49 (fig. 2). The chance of getting this value in February was 1 in 156. So, since June 2013, consecutively there were dry month, i.e. there was rainfall deficit (a meteorological drought) that consequently led to a hydrological drought.

\begin{tabular}{|c|c|c|c|c|c|c|c|c|c|c|c|c|}
\hline 2002 & -99 & -99 & -99 & 2.12 & -0.92 & -306 & -0.17 & -1.62 & -1.24 & 0.09 & -0.36 & 0.49 \\
\hline 2003 & 1.36 & -0.04 & -1.34 & 1.23 & 0.85 & 0.85 & 0.18 & -0.44 & -0.06 & 0.79 & 0.63 & 0.49 \\
\hline 2004 & -1.46 & 1.33 & -0.64 & 0.01 & 0.22 & 0.72 & 0.28 & 0.98 & 0.24 & 0.49 & 1.05 & -0.68 \\
\hline 2005 & -1. 42 & -0.30 & 1.13 & 0.18 & 1.26 & 1.17 & 0.96 & -0.70 & 0.21 & -10.16 & 1.30 & -0.27 \\
\hline 2006 & -0.19 & -0.85 & -0.65 & 0.65 & -0.50 & 0.14 & -1.02 & 0.64 & -1.19 & -1.73 & -10.32 & 4.69 \\
\hline 2007 & 1.21 & 1.85 & -0.74 & -0.57 & -1.92 & 1.77 & -1.63 & 0.15 & 1.64 & 0.81 & -10.48 & 0.21 \\
\hline 2008 & -0.15 & -0.12 & 1.54 & 0.91 & 0.60 & 1.38 & -1.93 & -0.03 & 1.16 & -0.33 & 0.40 & -0.90 \\
\hline 2009 & 0.86 & 0.56 & 0.93 & 1.20 & 1.71 & 0.68 & 1.04 & 0.49 & 0.84 & 0.79 & -0.19 & -1.42 \\
\hline 2010 & 0.77 & 1.06 & 1.66 & -0.54 & -1. 4.47 & 0.27 & -1.55 & 0.19 & -1.03 & 0.35 & -1.75 & -0.12 \\
\hline 2011 & -0.05 & -264 & 0.74 & 1.93 & 0.27 & -1.03 & 0.19 & 1.07 & -2.54 & 0.43 & -1.64 & -1.07 \\
\hline 2012 & 0.26 & -0.75 & 0.41 & -10.44 & 0.08 & -0.25 & -1.43 & -0.11 & -0.39 & -0.22 & -1.45 & 0.56 \\
\hline 2013 & 0.36 & -0.26 & -1.54 & -1.05 & -2.49 & 0.68 & 3.90 & 0.32 & -99 & -99 & -99 & -99 \\
\hline
\end{tabular}

Fig.3 Water Supply (min and max stats)

By March 2014 the water supply reservoirs of Batllava and Badove were at $25 \%$ of normal levels, and nearly exhausted. There was approximately not more than 6-8 weeks of water supply remaining for upwards of 500,000 citizens.

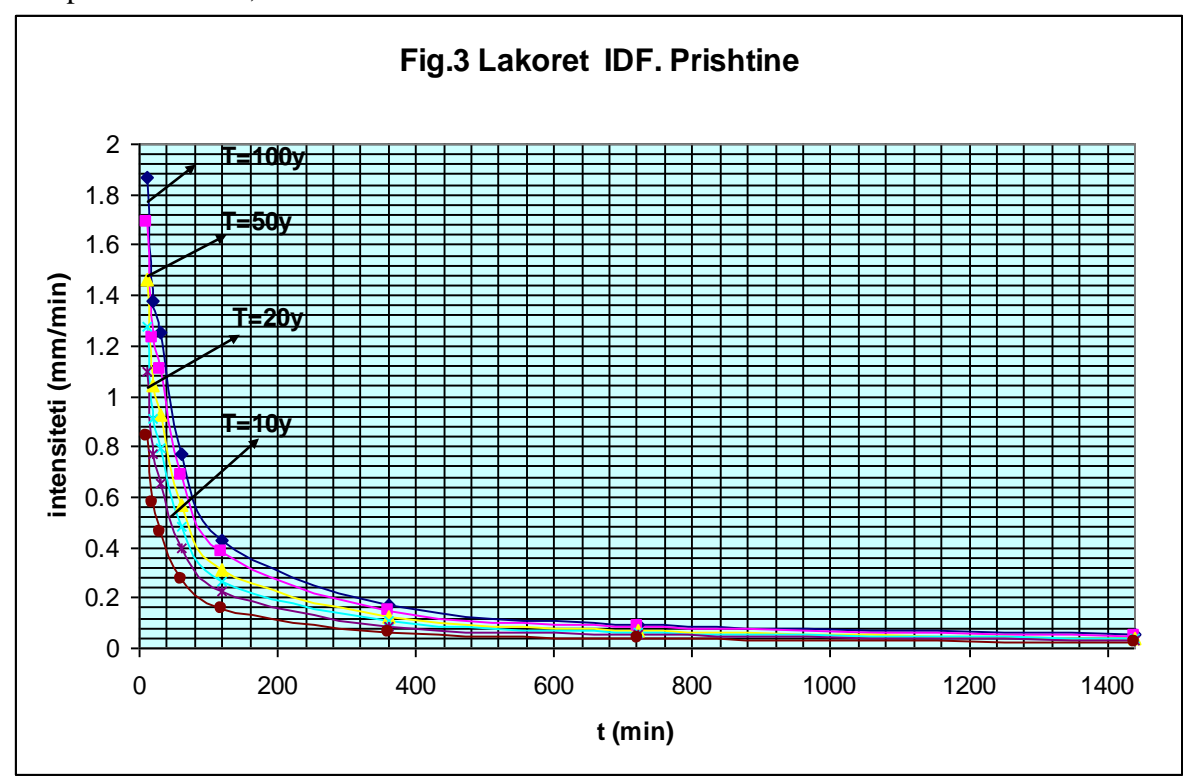

Graph.1 IDF Graphs 
International Conference on Civil Engineering, Infrastructure and Environment, Nov 2015

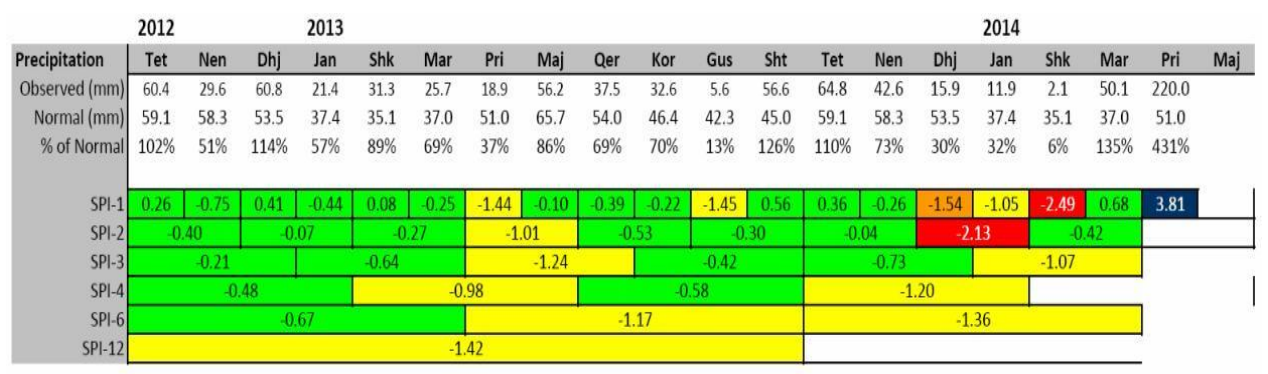

\begin{tabular}{l|lllllllllllllllllll} 
Storage & Tet Nen Dhj Jan Shk Mar Pri Maj Qer Kor Gus Sht Tet Nen Dhj Jan Shk Mar Pri Maj
\end{tabular}

Observed (m) \begin{tabular}{c|ccccccccccccccccccccc} 
& 630.36 & 630.07 & 629.69 & 627.9 & 628.08 & 630.57 & 631.53 & 630.98 & 630.15 & 629.02 & 627.87 & 626.74 & 625.55 & 624.49 & 623.49 & 622.53 & 621.83 & 621.35 & 630.04 & 634.00
\end{tabular}

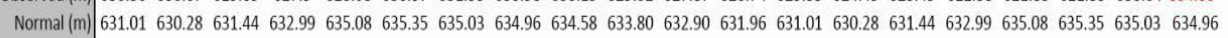

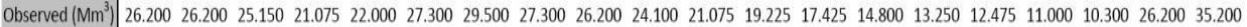

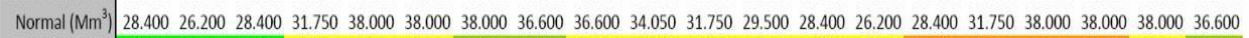

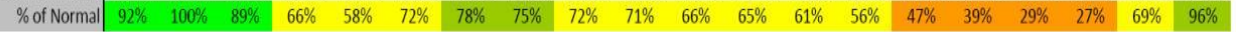

\begin{tabular}{l|llllllllllllllllllll} 
Production & Tet & Nen & Dhj & Jan & Shk & Mar & Pri & Maj & Qer & Kor & Gus & Sht & Tet & Nen & Dhj & Jan & Shk & Mar & Pri & Maj \\
\cline { 2 - 7 }
\end{tabular}

\begin{tabular}{l|cccccccccccccccccccc} 
Observed $\left(\mathrm{Mm}^{3}\right)$ & 2.100 & 2.100 & 2.100 & 2.218 & 1.956 & 2.131 & 2.145 & 2.104 & 2.166 & 2.035 & 2.059 & 2.165 & 2.108 & 2.006 & 2.032 & 1.936 & 1.468 & 1.538 & 1.521
\end{tabular}

Fig 4. - SPI Monitoring During Batllava Drought 2013/14

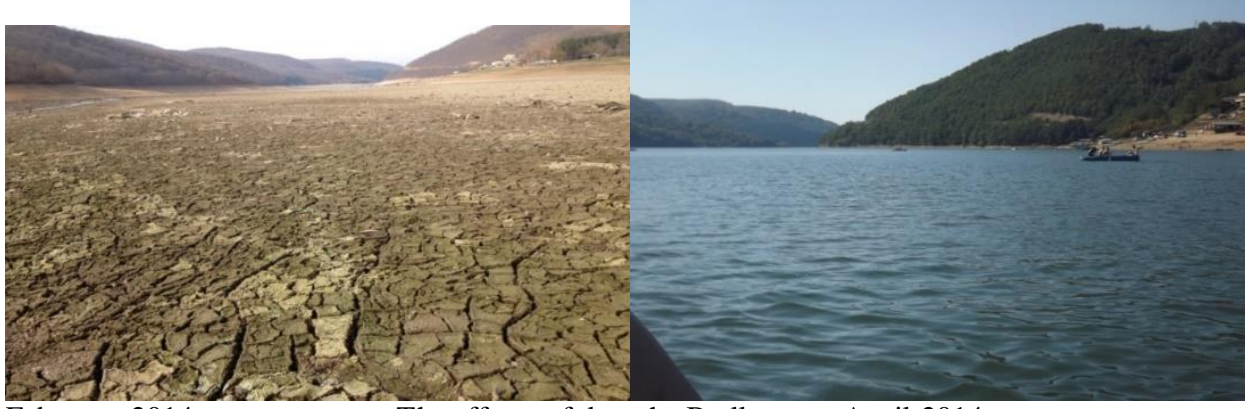

February-2014

The effects of drought-Batllava April-2014

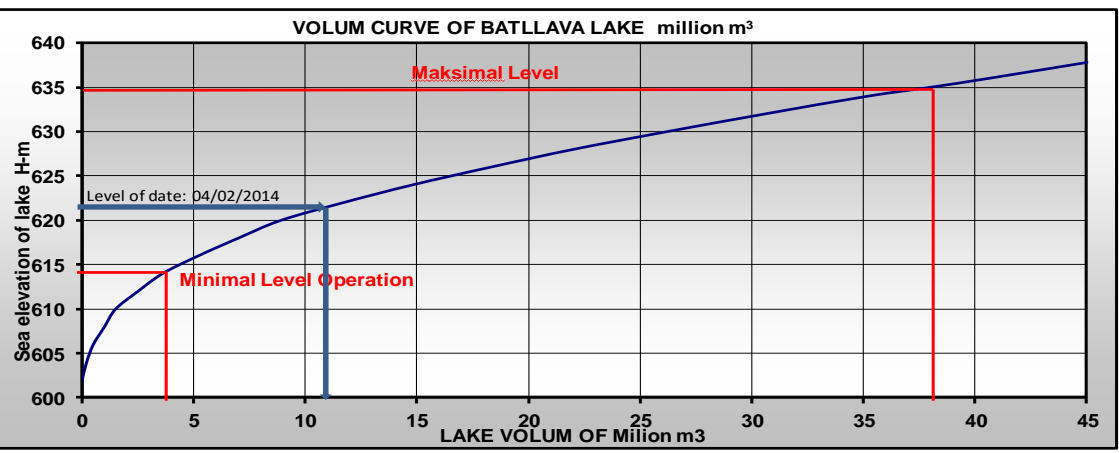

By March 2014 the water supply reservoirs of Batllava and Badovc (fig. 3), were at $25 \%$ of normal levels, and nearly exhausted. There was approximately not more than 6-8 weeks of water supply remaining for upwards of 500,000 citizens. 


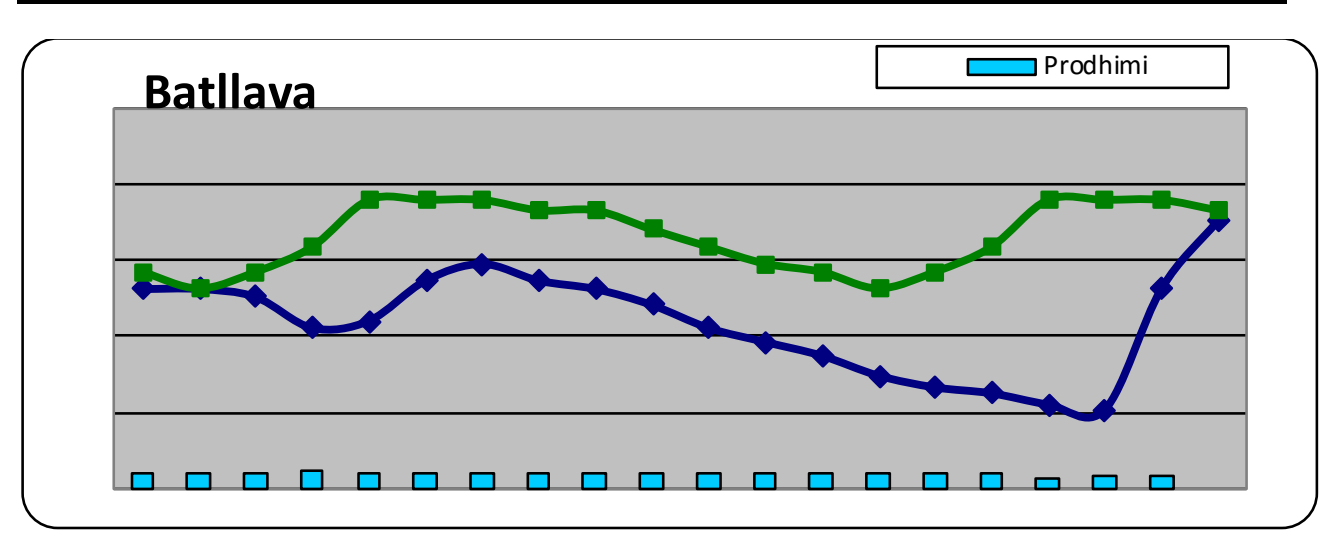

Fig 5. Batllava reservoir storage and production

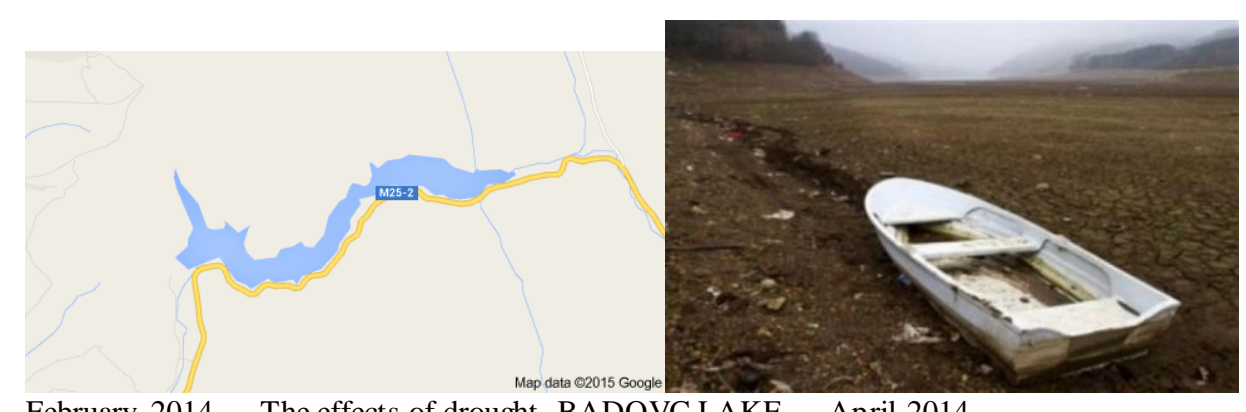

February-2014 The effects of drought- BADOVC LAKE April-2014

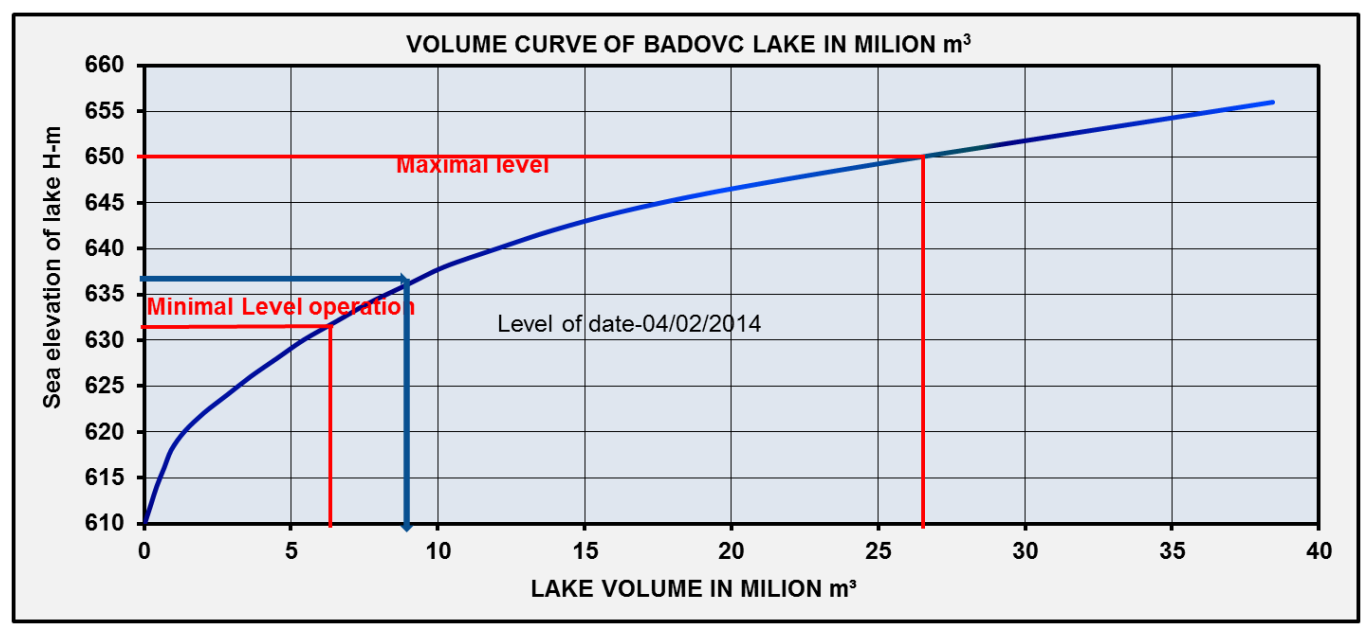

Graph 4.

Prishtina Regional Water Company prepared an emergency contingency plan to import water from Gazivoda - Ibër-Lepenc canal to the Badovc Reservoir which commenced in February 2014. This Plan, which involved considerable capital cost, IF fully operational would be able to import approximately $350 \mathrm{l} / \mathrm{s}(30.2 \mathrm{Ml} /$ day or $907 \mathrm{Ml} /$ month). The normal abstraction from Badovc is in the order of $710 \mathrm{Ml} /$ month, therefore the Gazivoda import should have theoretically allowed the continuing operation of the reservoir to limited parts of the city.

However, Badovc was at critically low levels, and the import scheme did nothing more than allow a continued supply. It did nothing to increase or restore the reservoir towards normal levels. Due to settlements alongside the canal discharging wastewater directly into the canal, the imported water 
risked being of very poor quality. Ministry of Environment and Spatial Planning together with the Prishtina municipality, Prishtina Regional Water Company and Ibër-Lepenc Company took measures to stop this practice. However, feedback from other municipalities alongside the canal, especially from Serbian upstream settlements indicated there was still some wastewater discharge. The water was nevertheless imported and was sent directly to the water treatment plant. This emergency measure was very expensive in terms of energy costs too.

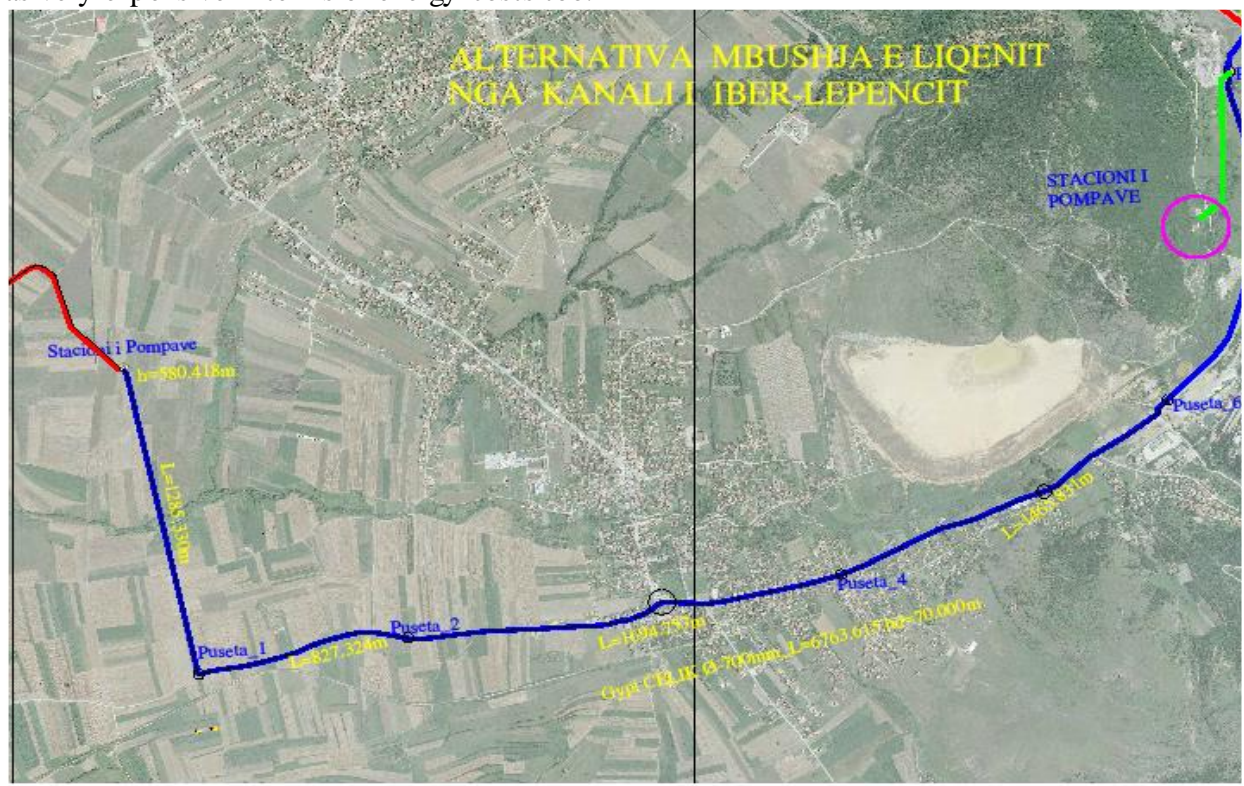

Ortofoto-Transmission pipe Iber-Lepenc canal to Badovc Lake

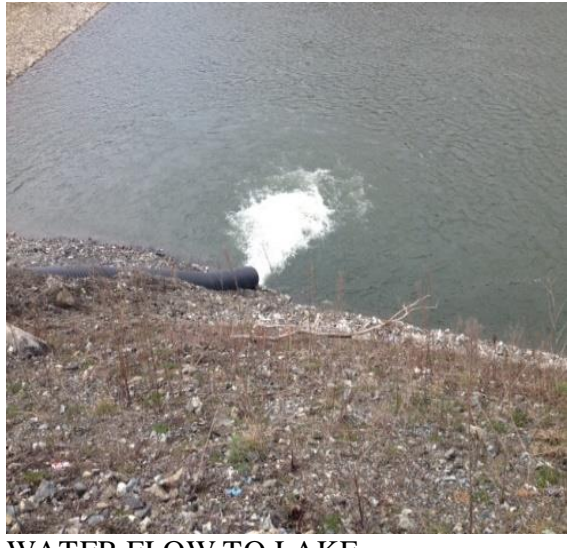

WATER FLOW TO LAKE

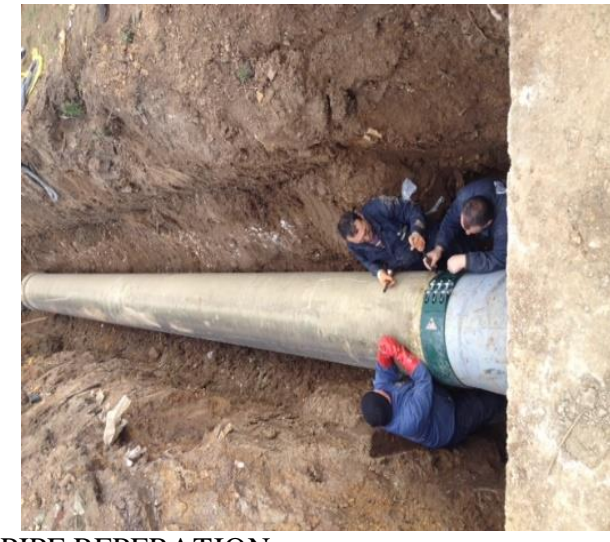

PIPE REPERATION

On the other hand, there was no ready 'Plan B' for Batllava Reservoir, which is larger and supplies a greater part of the city $(60 \%)$, although there were a couple of measures proposed to bring water directly from other streams into the reservoir. Each required a proper study and risked being implemented too late. Termination of water supplies from Batllava would have caused significant disruption and hardship to citizens.Analysis of precipitation statistics for Prishtina $(1926-2014)$ confirms that a severe or extreme meteorological drought of 4-6 months duration can be expected $21 \%$ of the time, or once every five years on average. 4-6 months of severe/extreme precipitation 
deficit will cause depletion in surface water resources, possibly leading to the potential failure of water supplies if the resources are not better managed.

It should be noted that the two SPI-6 precipitation periods April-September 2013 and October 2013March 2014 had values of -1.17 and -1.36 respectively (fig. 5). Since a Severe Drought technically starts only when SPI $=-1.5$, then the drought sequence in Kosovo was no more than a Moderate Drought. In spite of this all the reservoirs were brought to the point of failure through inadequate monitoring and inadequate understanding of precipitation versus reservoir supply-demand dy namics by the RWCs.

This raises concerns if Kosova was to be faced with an extended period of Severe Drought!

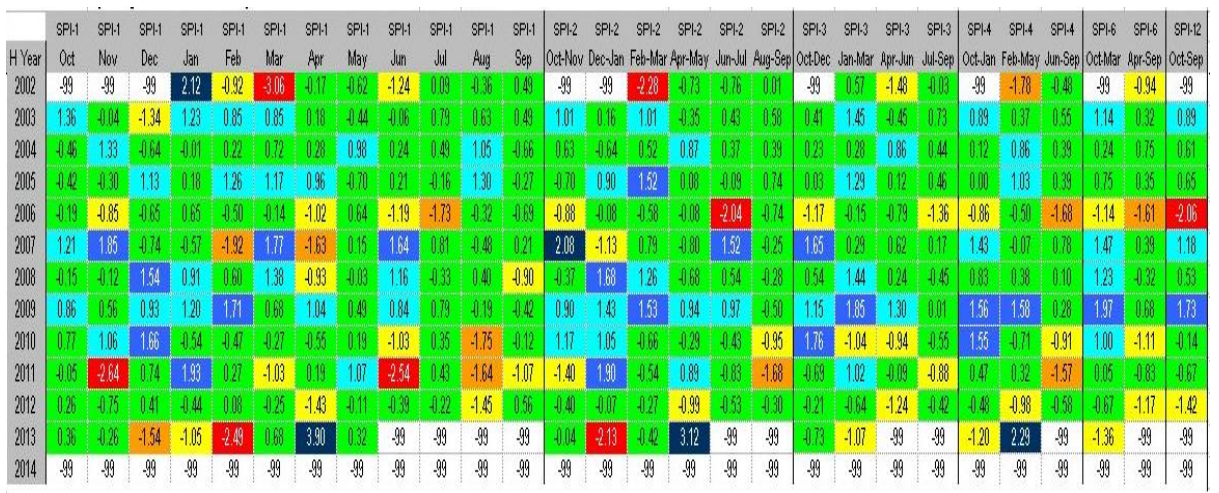

Fig 5. Monthly, bimonthly, quarterly, semi-annual and annual SPIs for Prishtina

The situation was only rescued by an extraordinary occurrence of extreme surplus precipitation in April that averted a catastrophe. In fact, April 2014 registered the wettest month in the recorded hy drometeorological history of Kosova, since 1927 with $227 \mathrm{~mm}$ precipitation, which expressed in Standardized Precipitation Index was 3.90! This means, that the chance of getting this value in April was 1 in 2000! Normal precipitation for the month of April would be $51 \mathrm{~mm}$.

This is a massive fluctuation from only 8 weeks earlier, in February 2014. Complacency that this was always going to happen has already rapidly set in.In order to avoid contentment and possible future failures, important lessons must be learned from the recent crisis. Precisely the same issues were encountered in 2007, and no action was taken to learn from that experience, with the consequence that almost the same lack of preparedness occurred six years later. Droughts (and floods) cannot of course be prevented. However, by continuous monitoring of precipitation and water levels in strategic rivers, more effective data processing, and the use of simple early warning systems, these can significantly improve regional level preparedness and resilience to floods and droughts.

Detailed analysis of the Prishtina precipitation record 1927-2014 confirms the statistical severity of the current meteorological drought. For example, the long-term annual average precipitation value for Prishtina is $582 \mathrm{~mm} / \mathrm{y}$ ear. Annual values of less than $480 \mathrm{~mm}$ represent moderate to severe drought situations. The hy drological year October 2012 - September $2013(436 \mathrm{~mm})$ was the fifth driest year since 1927 and December 2013 was also the fifth driest December since 1927 (16 $\mathrm{mm}$ compared to the average $59 \mathrm{~mm}$ ). August 2013 received $6 \mathrm{~mm}$ compared to the more normal $38 \mathrm{~mm}$.

The need for water conservation measures could therefore have been identified already in August 2013, if not earlier, if an Early Warning System (EWS) had been operating. With earlier conservation of water in the Batllava and Badovc

\section{Reference}

1. RWC"Prishtina"j.s.c

2. Kosovo Hydrometeorological Institute

3. GIZ 